\title{
KONSEP EKONOMI ISLAM PADA MASA DINASTI
}

Oleh :

Sri Maghfirah (90100118029)

Ekonomi Islam A

\section{srimaghfirah@icloud.com}

\section{MASA PEMERINTAHAN BANI UMAYYAH}

\section{Muawiyah bin Abi Sufyan}

Dimasa pemerintahan Muawiyah bin Abi Sufyan beliau membangun kantor catatan negara dan layanan pos (al-barid) serta seluruh fasilitas pendukungnya, membangun kekuatan militer yang kuat dan pemberian gaji tetap, membangun birokrasi (pajak dan administrasi publik) dan mengembangkan jabatan qadi (hakim) sebagai jabatan profesional. Para qadi dimasa itu dalam membuat keputusan suatu kasus tidak terpanguruh oleh kekuasaan pemimpin negara atau kebijakan politik sehingga mereka bebas mengambil keputusan termasuk yang berkaitan dengan para pejabat tinggi negara. ${ }^{1}$

\section{Abdul Malik bin Marwan}

Pada masa kepemimpinan Abdul Malik yaitu berupa pemikiran yang serius untuk menciptakan mata uang sendiri sebagai salah satu alat tukar. Selain itu kebijakan pada masa Abdul Malik, beliau memberikan hukuman Ta'zir (hukuman yang tidak ditentukan oleh al-Qur'an dan hadist yang berkaitan dengan kejahatan yang melanggar hak Allah dan hak hamba yang bertujuan untuk memberikan pelajaran kepada si terhukum dan mencegahnya mengulangi perbuatannya. ${ }^{2}$ Kebijakan lain yang dihasilkan Abdul Malik yaitu beliau membenahi administrasi pemerintahan disertai pemberlakuan penggunaan bahasa Arab sebagai bahasa resmi pemerintahan Islam.

\section{Umar bin Abdul Aziz}

\footnotetext{
${ }^{1}$ Rizem, 'Perekonomian Di Masa Dinasti Umayyah: Sebuah Kajian Moneter Dan Fiskal', Indonesian Interdisciplinary Journal of Sharia Economics (IIJSE), 3.1 (2015), 32.

2 Darsi Darsi and Halil Husairi, 'Ta'zir Dalam Perspektif Fiqh Jinayat', Al-Qisthu: Jurnal Kajian IImu-IImu Hukum, 16.2 (2018), 60 <https://doi.org/10.32694/010500>.
} 
Umar bin Abdul Aziz merupakan khalifah ke delapan pada pemerintahan Dinasti Umayyah. ${ }^{3}$ Pada masa pemerintahannya beliau menerapkan kebijakan ekonomi islam berupa mengembalikan harta pribadi dan keluarga kepada baitul mal, menetapkan gaji pejabat dan dilarang memiliki kerja sampingan agar orang yang kurang mampu mendapat bagian pekerjaan agar bisa memenuhi kebutuhan hidupnya, memprioritaskan pembagunan dalam negeri serta menghapus pajak terhadap kaum muslim, mengurangi pajak kaum nasrani dan membasmi kerja paksa.

\section{MASA PEMERINTAHAN BANI ABBASIYAH}

\section{Abu Ja'far Al-Mansur}

Pada tahun 693 khalifah Abdul Malik menetapkan untuk mencetak uang sendiri di Damaskus. Kebijakan tersebut sangat berpengaruh terhadap perekonomian dinasti itu. Sebab kita lihat bahwa sebelum diberlakukannya kebijakan ini mata uang yang beredar sebagai alat tukar adalah mata uang Roma dan mata uang Persia yaitu dirham dan dinar. ${ }^{4}$ Selain itu kebijakan lain yang diterapkan beliau adalah penertiban administrasi birokrasi, berpegang teguh dalam kedudukan keuangan negara dan hemat membelanjakan uang negara.

\section{Harun Ar-Rasyid}

Konsep pemikiran yang dianut oleh bani Abbas yaitu pemimpin memperoleh hak memerintah dari Allah, bukan dari manusia karena itu penguasa hanya bertanggungjawab kepada Tuhan. Pada masa Harun Ar-Rasyid pengelolaan keuangan dan penyelenggaraan keadilan beliau serahkan kepada yang lain, namun dalam urusan masyarakat papan atas beliau adalah pemimpin yang aktif dari segalanya. Pada saat itu, kegiatan ekonomi banyak terjadi pertukaran barang serta valuta dari berbagai penjuru sehingga negara banyak memperoleh pendapatan dari kegiatan ekonomi tersebut..$^{5}$ Beliau juga fokus ke perpajakan diantaranya al Muhassabah, al- Muqasamah dan al-Muqqatha'ah).

\footnotetext{
${ }^{3}$ Kuliman Harahap, 'Kebijakan Pengelolaan Keuangan Publik Pada Masa Kekhalifahan Umar Bin Abdul Aziz', Jurnal Ipteks Terapan, 8.2 (2016), 61 <https://doi.org/10.22216/jit.2014.v8i2.424>.

${ }^{4}$ Naila Farah, 'Perkembangan Ekonomi Dan Administrasi Pada Masa Bani Umayyah Dan Bani Abbasiyah', Jurnal Kajian Ekonomi Dan Perbankan Syari'ah, 6.2 (2014), 32.

${ }^{5}$ Kasmiati, 'HARUN AR-RASYID Oleh Kasmiati STAIN Datokarama Palu, Jurusan Tarbiyah', Jurnal Hanafa, 3 (2006), 96.
} 